\title{
Gloria Isabel Ocampo, Poderes regionales, clientelismo y Estado: etnografías del poder y la política en Córdoba, Colombia, Bogotá, Colección Territorio, Poder y Conflicto, CINEP-PROGRAMA POR LA PAZ - ODECOFI - COLCIENCIAS, primera reimpresión 2015.
}

Por Andrés Dávila

$\mathrm{E}$ n este libro de más de trescientas páginas, que consta de una Introducción, Seis capítulos organizados en dos partes, un Epílogo y Conclusiones, la autora hace una disección cuidadosa, minuciosa, del poder político regional en Córdoba. Esto que acabo de afirmar tiene varios significados que me permito desarrollar a continuación. Inicialmente, reconstruyendo con rigor la ruta explicativa seguida por la autora. Posteriormente, resaltando los hitos que, a mi manera de ver, constituyen aportes centrales del trabajo para una mejor comprensión y discusión de la política colombiana hoy y hacia el futuro.

En relación con el texto, es importante señalar que comienza con el prólogo escrito por Fernán González quien de manera clara y suscinta establece con precisión el lugar del trabajo dentro de la colección y, me atrevo a decir, dentro de su propuesta más abarcante de interpretación del Poder y la Violencia en Colombia. Las particularidades del caso del Departamento de Córdoba son allí claramente expuestas para efectos de considerar adecuadamente los alcances y límites del trabajo: se ilustra 
la relación entre una región de mayor integración y articulación económica, social y política con el Estado y la nación colombiana, a partir del desarrollo y configuración de las relaciones clientelistas. Y para ello, señala el prologuista, la autora parte de los poderes regionales, sus negociaciones, sus alianzas, sus cambios, sus diferencias y rupturas, para establecer una particular interacción con el Estado y el régimen político. Si se quiere, se desentraña la configuración y funcionamiento del sistema político regional para dar cuenta del complejo entramado de relaciones que establece con el centro y sus oleadas de modernización, burocratización, tecnocratización. Y ello lo hace acudiendo a las herramientas de la antropología, especialmente la etnografía, la sociología, la ciencia política, la historia, en una amalgama fluida que conduce a explicar cómo se transforma y se conserva el poder político regional. El prologuista llama la atención sobre el aporte significativo, importante, ilustrativo en la relectura pausada, no escandalosa, tampoco ingenua, del clientelismo y su capacidad para reinventarse como relación de intermediación clave en todo lo sucedido.

En la introducción, la autora cumple con indicarnos su punto de partida, sus referentes conceptuales, teóricos y metodológicos, anclados en un juego de espejos magníficamente logrados: la configuración del poder político regional en permanente referencia con la construcción paradójica, contradictoria, del Estado. Y allí, en el centro de todo, primero el patronazgo y, después, el clientelismo. Como toda buena introducción, queda clara cuál es la ruta a seguir y cuál el nexo sólido que articula este trabajo con la colección y con el aporte fundamental de Fernán González en Poder y Violencia en Colombia, especialmente en las referencias a una adecuada comprensión de cómo se construye el Estado. Y allí, una idea fuerza muy relevante: siguiendo a Michael Mann, la consideración de cómo la configuración del Estado "no destruye sino que articula y reutiliza los mecanismos previos de poder” (pág. 16).

En la primera parte, que consta de tres capítulos, esa ruta va de una mirada primigenia a las características de integración económica y po- 
lítica de la región, con una mirada detallada, casi de revista del espectáculo, sobre la conformación de las elites regionales a partir de los lazos familiares y de consanguinidad, que van dando lugar a la creación del Departamento de Córdoba. La cuestión de la hacienda y del patronazgo abre un lugar a la primera consideración en torno a liderazgos, facciones y partidos. Luego, en el segundo capítulo, se concentra en establecer los fundamentos y los principios que dan orden al poder político regional: allí la disección es profunda y fría, adhesiones, lealtades, compromisos, deudas de afecto y económicas que van tejiendo las redes reales e imaginarias del poder político. Aparecen con mayor detalle las gráficas que desentrañan las redes familiares y del poder político que desde mediados del siglo XX se configuraron y se fueron transformando, bajo un modelo que inevitablemente conduce a lo que la autora denomina “el carácter segmentario del sistema político” (pág. 115.). La primera parte se cierra, en el tercer capítulo, con la aparición, para quedarse transformándose, del clientelismo electoral, en la medida en que la labor política se "profesionaliza”, pero a su vez los lazos familiares y sociales continúan como un transfondo necesario en la conformación y permanencia del poder (o más bien habría que decir “de los poderes”) político regional.

En la segunda parte, la cuestión se centra en la relación entre poderes regionales, partidos políticos y Estado. En realidad, se trata de complementar lo planteado en la primera con la evolución o involución de esta compleja relación hasta llegar a las coyunturas más recientes. El capítulo 4 se detiene a establecer cómo se ordenan los poderes políticos regionales en la interacción entre el Estado central y la región. Un Estado central que cambia de modelo, que aparentemente se moderniza y que irradia políticas, reglas y modos de intervenir del centro hacia las regiones. Un examen muy importante de este capítulo se refiere a las continuidades y rupturas que van de los auxilios parlamentarios a la mermelada santista. Otro, a la distribución de la institucionalidad estatal entre los poderes regionales y las dinámicas positivas, propositivas y perversas de tales interacciones y distribuciones. El capítulo 
5 se concentra en las reformas políticas, los poderes regionales y los partidos políticos. Aquí la autora hace su tránsito de la antropología a la ciencia política, con muchos devaneos en la sociología política. Partidos, sistema electoral, elección popular de autoridades locales son, nuevamente, diseccionadas con frialdad y finura para permitirnos entender como esas transformaciones inducidas desde lo nacional son finalmente apropiadas, tergiversadas, redefinidas bajo las lógicas potentes de configuración de los poderes regionales. Y no es que estos no cambien y se adapten y adecúen a cambios en las reglas y en las relaciones, pero conservan una capacidad enorme para traducirlo bajo lógicas que finalmente nos regresan a los primeros capítulos. Y claro, hay reacomodos y relevos: de partidos, de familias, de generaciones, de elites, de liderazgos. Pero a todos ellos subyacen dinámicas que tienen demasiado que ver con las lógicas de la política regional desde hace mucho. Finalmente, en el capítulo 6 se aborda la cuestión paramilitar. Hace poco leí el texto de María Teresa Ronderos que nos cuenta la historia desde allí, desde lo paramilitar. Gloria Isabel la cuenta desde acá. Y hay coincidencias y los hechos, al final, conforman una sola historia. Sin embargo y aunque la autora es muy cuidadosa en sus interpretaciones y conclusiones, queda explícitamente planteada una muy necesaria relectura de lo que hemos denominado la parapolítica. Claro, si el afán principal es entender y explicar.

El epílogo y la conclusión hay que leerlos en clave de una necesaria relectura del clientelismo.

Hasta aquí, una somera referencia a un texto que requiere ser leído para entender cómo se desenvuelve la política en las regiones y cómo se explica lo que a hoy son escandolas cotidianas de periodistas, medios y analistas. Quiero ahora señalar, puntualizando, algunos grandes asuntos que el texto pone en remojo.

En lo conceptual y metodológico, es un texto para enseñar a leer la política en lo regional. Pero quiero resaltar las gráficas que resumen y 
potencian los lazos familiares, sociales, partidistas y políticos de Córdoba. Casi que son un ejemplo de lo que se requiere para todas las demás regiones, departamentos.

En el análisis de la relación Estado central-poderes regionales, Estados moderno-poderes tradicionales en cambio, es un ejemplo de cómo aproximarse a esta compleja cuestión. Debería incluirse como texto obligatorio para todo funcionario del DNP y de los asesores y directores de los ministerios.

En el análisis de cómo lo familiar-social, las sociabilidades, se reinventan, perduran, se apropian de, el texto es un rico repertorio de ejemplos para entender por qué y cómo resulta tan difícil construir ciudadanías y modernidad. Pero a la vez, por qué es tan inoficiosamente peligroso seguir desde el centro y desde una mirada ignorante, ingenua, moralista, desconociendo que así son las cosas e insistiendo en miradas clínicas que solo ven corrupción, parapolítica, y que confunden y no diferencian los alcances del clientelismo.

En el análisis del clientelismo, comprueba algo que debería ser claro: no se acababa con el paso a una sociedad predominantemente urbana y moderna. Por el contrario, allí está y allí se ha quedado: transformándose, adaptándose, eventualmente monetizándose, eventualmente también inmiscuyéndose en los programas sociales, en la contratación pública, en la venta del voto, incluso acompañando los embates paramilitares o de cierto populismo caudillista que se intentó para reemplazarlo. Pero no solo eso. Si bien es claro que el clientelismo es asimétrico y cierra canales de movilidad, también es cierto que ha sido en la realidad real un enorme mecanismo de inclusión. Una relación de intermediación que, como los partidos, se niega a desaparecer.

Y en cuanto a los partidos, valga decir que el caso de Córdoba resulta muy interesante para repensar la supuesta crisis y desaparición del bipartidismo en Colombia. 
Bueno, espero con esto dar elementos para invitar a su lectura, a su apropiación, a su discusión. Y finalmente, quiero felicitar a la autora y obviamente a los gestores de toda la colección por darnos posibilidades de conocer mejor el país. 